\title{
Identifying the stereotypical who, what, and why of physics and biology
}

\author{
Megan Bruun, ${ }^{1, *}$ Shannon Willoughby, ${ }^{2}$ and Jessi L. Smith ${ }^{3}$ \\ ${ }^{1}$ Department of Psychology, Montana State University, Bozeman, Montana 59717, USA \\ ${ }^{2}$ Department of Physics, Montana State University, Bozeman, Montana 59717, USA \\ ${ }^{3}$ Office of Research, University of Colorado, Colorado Springs, Colorado Springs, Colorado 80918, USA
}

(Received 13 April 2018; published 12 December 2018)

\begin{abstract}
Supporting efforts to grow the scientific workforce means articulating and comparing the content of science field stereotypes. To do this, data were collected from the general public [undergraduates $(n=121)$ and Amazon Mechanical Turk workers $(n=223)$ ] as well as from people within science [attendees of an undergraduate conference for women in physics $(n=34)]$. Participants were randomly assigned to consider either biologists or physicists and then produce both spontaneous judgments and rate various person traits (e.g., ratings related to looks and personality and hobbies) and field characteristics (e.g., ratings related to the working conditions, norms, and expectations for the field). Analyses show stereotypes of the scientist and the science field were statistically significantly negative overall, with stereotypes about physicists and the field of physics more negative than biology. Compared to biologists, physicists were perceived as statistically significantly more competent, but statistically significantly more unattractive, tech oriented, awkward, and loners. Furthermore, compared to biology, a job in physics was viewed as having fewer opportunities for working with and helping others, but more opportunities for agency, a greater requirement for innate brilliance and effort to succeed, and as more difficult. That said, physicists were more envied than biologists. Data were triangulated with open-ended responses illustrating that across samples, people are more likely to reproduce science stereotypes for physicists. Implications for stereotype research and broadening participation of the science workforce are discussed, with a focus on the utility of role models and classroom interventions that negate stereotypes such as writing activities and encouraging students to approach physics with a growth mindset. Instructors are encouraged to consider what stereotypes students have about the field of physics and physicists. At the department level, instructors are encouraged to consider hosting a Conference for Undergraduate Women in Physics sponsored in part by the American Physical Society.
\end{abstract}

DOI: 10.1103/PhysRevPhysEducRes.14.020125

\section{INTRODUCTION}

A biology professor who participated in the 2017 U.S. March for Science was quoted as saying "It's not just old white men sitting in a dusty laboratory. We are diverse." [1]. Whether or not science is diverse, depends on the definition of diversity [2]. People of different genders, races, ethnicities, sexual orientations, and socioeconomic backgrounds are not well represented in the scientific community [3-7]. There is an undeniable descriptive truth

\footnotetext{
Corresponding author. meganpbruun@gmail.com

Present address: Department of Psychology, Montana State University, 406 Traphagen Hall, Bozeman, Montana 59717, USA.

Published by the American Physical Society under the terms of the Creative Commons Attribution 4.0 International license. Further distribution of this work must maintain attribution to the author(s) and the published article's title, journal citation, and DOI.
}

to the "old white man" science stereotype. Indeed, according to NSF indicators, in 2014 nearly 60\% of physics faculty in the U.S. were white men [6]. In contrast, only $45 \%$ of biology faculty in the U.S. during that same time frame were white men [6]. Such stereotypes are important because the public's view of science and scientists, and the scientist's view of the public's view, has implications for recruitment and retention efforts that ironically can reproduce the stereotypes [7-11].

So why should physicists study stereotypes? It is likely that the typical physicist has heard the term "stereotype." Indeed, we all have stereotypes about various groups of people and places. However, a physicist's understanding of how to define a stereotype is probably less nuanced compared to how social scientists define the term. In order to inform the physics education research (PER) community about how stereotypes are defined, and to better understand the types of stereotypes that people have regarding physicists and physics as a profession, we have taken a collaborative approach between physics and social psychology for this research project. Our research team consists of three 
white queer women, who are at different stages of our academic careers (one graduate student, one assistant professor, and one full professor). We take our inspiration from a recent article in Physics Today that prompts us all to adopt the goal of: "finding and leveraging interdisciplinary opportunities with the objective of enhancing your value and that of your enterprise" [12].

We argue that our collaboration which brings together physicists and psychologists is an informative way to approach stereotypes because psychologists can help us better understand what stereotypes people have regarding physics, and we as professional physicists can in turn use this information to directly address and combat these stereotypes. By combating specific aspects of common stereotypes (such as social isolation), we can work to recruit a more diverse group of students to the world of physics. This dovetails with other goals that have been spelled out, including creating classroom instruction that is unbiased [13] and realizing that faculty can be quite influential when students are choosing a major [14]. Further, perhaps we ought to think more broadly about stereotypes when developing research questions [15], and consider whether or not the goal is, as Traxler and colleagues put it: "to change (students from diverse backgrounds) so that they can succeed in a culture where men are successful, or would it be better to change the culture so that the experience of (straight white married cis-gendered) men is not assumed the standard?" [15].

Disrupting the stereotypes of science starts by articulating their specific content. There might be an intuitive understanding of an "old white man sitting in a dusty laboratory" but we ask, what exactly does that mean? Furthermore, is there a monolithic view of science, or do certain fields (that are more and less diverse) have distinct stereotypes about the person (appearance, behaviors, personalities, and attitudes) and the field's working conditions and values? To start this descriptive process, we answer a call to action for articulating the content of physics stereotypes of which little is known [16] and compare physicists or physics stereotypes to the stereotypes of the relatively more diverse field of biology.

Compared to physics, biology is more diverse when measured by the percentage of doctorates awarded to people who identify as women, but physics is more diverse when measured by percentage of doctorates awarded to people from nonwhite racial and ethnic backgrounds. According to 2014 data from the NSF [6] there were many more Ph.D.'s granted in biology (8207) compared to physics (1768), and of those awarded degrees, 53.3\% of biology Ph.D.'s were earned by women, as opposed to $18.7 \%$ of physics Ph.D.'s. When considering race and ethnicity, $49.5 \%$ of Ph.D.'s earned in biology were awarded to people who identify as "white." This was the case for only $39.3 \%$ for physics Ph.D.'s. This difference in ethnicity and race might be somewhat attributable to the $46 \%$ of physics doctorates awarded in 2014 to temporary residents, whereas that was the case for only $27 \%$ of biology doctorates awarded. These differences are of importance because stereotypes can be both a cause and consequence of a field's demographic characteristics [17]. Indeed, there is a corresponding inference from a group's under- or overrepresented in a particular field, that perpetuates the group's stereotypes [18]. In turn, these stereotypes serve as cues for what groups are viewed as suited for a field (or not), which contributes to that very same under or overrepresentation in that field; which, then feeds back into the stereotype. The result is a reproducing cycle that is difficult to break [18]. For example, black men are overrepresented as professional athletes, which reinforces the stereotype that black men are athletic, which contributes to black men being more valued for their athletic ability (and not their intellectual ability) which can result in black men being more likely to be selected for and opt into sports [19]. Thus, the associations between demographics and stereotypes in science are cyclical and the attributes and traits associated with what it takes to be a physicists or biologists should correspond with people's stereotypes of the groups who dominate each field [18].

Stereotypes are overgeneralized thoughts about a group (in this case of people or domains) [20] that provide easily accessible, perhaps even inescapable, information that influences how people think and behave [11,21,22]. Stereotypes impact recruitment and retention efforts by cueing to people that they do not belong in a field [23-25], that they might encounter discrimination and microagressions [26], and even that their romantic pursuits might be hampered if they pursue a science career [27]. For example, even when a person does not personally endorse stereotypes, just knowing that the stereotypes exist and could possibly be used to interpret behavior results in a "stereotype threat" that depletes women's and minorities performance and motivation on the stereotype-relevant task [11,22].

Also, stereotypes are a driving force in an overall system that reproduces itself through implicit associations $[10,28]$, shifting standards [29], and privileging one certain way of understanding the world [30,31] that exerts influence on what tasks and domains people are selected into [32-35] and a person's performance and motivation once engaged in the task or domain [11,36-38]. For example, when a national sample of science faculty were asked to evaluate an applicant for a lab manager position, the applicant with a female name (Jennifer) was less likely to be deemed hirable compared to the same application with a male name (John) [32]. In this example, relying on gender stereotypes to infer suitability for the science position resulted in the man being deemed more hirable, suggested for a larger salary, and as someone more likely to be mentored to continue progressing in the science workforce pipeline.

Finally, stereotypes also provide information not just about who is likely to succeed, but also trigger 
overgeneralizations about the type of work involved. For example, the stereotype that a science field values innate brilliance over hard work undermines academic motivation [39] and the stereotype that a science field undervalues working with and helping other people dampens the career pursuits of women, Native American, and Latino students [24,40,41]. Science stereotypes do not only hinder the marginalized and oppressed; everyone's motivation and performance can benefit when field and person stereotypes are dismantled $[42,43]$.

The psychology literature is replete with analyses of the public's general stereotypes across science fields. For example, decades of research reveal that when the average American thinks of a scientist, they think of a white man who embodies the "nerd" stereotype of lacking interpersonal skills, robotic, and singularly focused on his subject, unattractive and highly intelligent, with a questionable moral compass [44-47]. Although there is a smattering of analyses of the heteronormativity and masculinity of some subfields of engineering and science [5,16,48], little to nothing is known about physics in particular, as Cheryan et al. [16] note in their extensive review of the STEM stereotyping literature: "We were unable to find studies of American students' stereotypes of physics" (p. 9). Taking our lead from Cheryan et al. [16], we focus on both the stereotypes of physicists themselves and the more general field of physics and compare these stereotypes with biology. The research question we are asking is: What does the general public think, and what do neophyte physicists assume are the stereotypes held by others? To answer this question, we form a collaboration between physics and psychology disciplines, to help broaden the understanding of what stereotypes exist about physicists and about the field generally. Using the tools of social science to inform the stereotypes of physics can allow educators to better break down these stereotypes.

\section{METHOD}

\section{A. Participants}

The final sample consisted of $n=378$ participants drawn from three populations as follows:

General undergraduate student sample.-A total of $n=$ 140 participants enrolled in an introductory psychology class participated for course credit $\left(M_{\text {age }}=20.97\right.$ years, $\mathrm{SD}=5.28 ; 56 \%$ female, $35.8 \%$ male, $8.2 \%$ unreported; $78.4 \%$ white; $3.7 \%$ Latino/a, $3.7 \%$ Native American, $0.7 \%$ Asian, $4.5 \%$ more than one ethnicity). Of these, $6 \%$ were missing data, and $3 \%$ did not pass one or more attention checks. This left a total of $n=121$ with usable data.

Amazon Mechanical Turk sample.-To recruit a more general sample we used Mechanical Turk, an online crowdsourced platform operated by Amazon.com. MTurk workers are generally savvy internet users who are frank in their survey responses, are often more educated, but less extroverted, than typical college samples [49]. Research shows that MTurk participants are typically older and more nonwhite than standard internet samples, and often represent more geographical locations [50]. Research also shows MTurk samples produce responses that are psychometrically reliable with high test-retest reliability [50].

A completed captcha was required for participants to take our MTurk survey. A total of $n=274$ MTurk workers participated in exchange for 50 cents (U.S.) $\left(M_{\text {age }}=36.05\right.$ years, $\mathrm{SD}=10.55 ; 48.4 \%$ female, $42.2 \%$ male, $9.4 \%$ unreported; $74 \%$ white; $3.6 \%$ Latino/a, $3.6 \%$ black, $7.6 \%$ Asian, $2.2 \%$ more than one ethnicity). Of these, $<1 \%$ were missing data, and $18 \%$ did not pass one or more attention checks. This left a total of $n=223$ with usable data.

Undergraduate women in physics conference sample.A total of 42 people attending a regional conference for undergraduate women in physics served as our "insider" sample $\left(\mathrm{M}_{\mathrm{age}}=23.07\right.$ years, $\mathrm{SD}=5.45 ; 70.6 \%$ female, $5.9 \%$ male, $23.5 \%$ unreported; $61.8 \%$ white; $2.9 \%$ Latino/ a, $5.9 \%$ Asian, $8.8 \%$ more than one ethnicity). Of these, $19 \%$ were missing data, and all passed the attention checks. This left a total of $n=34$ with usable data. The participants were primarily advanced undergraduate students, with some graduate student and junior faculty volunteers. All participants (volunteers and students) were majors in or otherwise connected to the physics workforce. Because survey participants did not receive any incentive, we opted to keep the online survey very short, asking only a subset of questions as detailed below.

\section{B. Procedure}

Participants in the general student sample and in the MTurk sample were randomly assigned to answer questions about either physicists or biologists; the undergraduate conference attendees only reported on physicists. Everyone completed the measures online, although the general student sample completed measures in a $30 \mathrm{~min}$ inperson session whereas the MTurk participants and the conference participants were given a link to a shorter 10-min online survey. The time difference of the surveys was due to a research assistant controlling the flow of the study in the in-person session as well as reading instructions out loud. The time difference was also impacted by the in-person session including additional exploratory items.

For all participants, the survey was introduced as a tool to better understand "what the typical person thinks about various college majors, research programs, and people in science." All participants completed the survey online with the open-ended questions first, the surveys second, and then demographics. The open-ended questions and survey questions were counterbalancing meaning that participants were presented with survey items in a randomized order. This means that participants completed the items in a different order to help reduce the possible impacts of any carry-over effects from the items. 


\section{Materials}

Characteristics about people.-Stereotypes related to looks, personality, and hobbies were examined as "characteristics about people." See Table I for all measures collected, example items, and the Cronbach's $\alpha$. The technique of focusing on "how most view" a group was used to reduce the social desirability of participants who might feel like they must answer in a particular way, following protocols in other social psychology studies on stereotypes [51-53].

Characteristics about the field.-Participants also rated items that assessed their views of society's beliefs and expectations about the working conditions in physics or biology as well as the norms, and expectations for the field. Instructions were adapted from Devine and Elliot [52] with items modeled after Allen and Smith's research on nursing and teaching field perceptions [53] meant to minimize participant's worry about answering in a "correct" or "socially desirable" way by asking participants to report on society's beliefs, and then answering how similar their own beliefs are to societies (see below). Again, see Table I for information on all measures collected.

Similarity to societal views. - After providing their ratings for each scale, all participants were asked "overall, please rate the extent to which your beliefs and expectations are similar to society's beliefs and expectations that you rated above" on a scale of 1 (not at all similar) to 5 (very similar) modeled after Devine and Elliot [52] and Allen and Smith [53].

Emotions towards scientists.- The eight items from the Behaviors from Intergroup Affect and Stereotypes "Map" [51] were used to assess "feelings that people in America have toward biologists (or) physicists as a group", see Table I for more information.
Spontaneous stereotype assessment of appearance, actions, and interests.-Participants in the general student sample and MTurk sample were asked open-ended questions about appearance, (i.e., "what do you think physicists or biologists looks like?") behaviors (i.e., "what do you think a typical physicist or biologist acts like?") and interests (i.e., "what do you think a typical physicist or biologist likes to do for fun?"). Conference attendees (who were all in physics) were asked the same appearance, behaviors, and interests items but framed as "describe what most people think a typical physicist looks like, acts like, likes to do for fun." These items were modeled after research examining stereotypical perceptions of computer scientists [45]. All open-ended items were presented to participants at the beginning of the study before any structured measures were used to avoid supplying stereotypical material to participants for the open-ended questions.

The spontaneous stereotype assessment of appearance, behaviors, and interests were coded by 4 research assistants who were unaware of the study goals, with each response coded by 2 coders. The interrater reliability ranged from $79 \%$ to $88 \%$. Disagreements were discussed and ultimately a graduate student acted as a third coder for any discrepancies. For each of the three questions, coders were asked to rate stereotypicality (yes or no) as well as whether the participant "explicitly resisted" and fought against any stereotypes (yes or no). A stereotypical response was coded yes, for example, when it read "a biologist would be a man, in his mid to late 30s, wearing glasses, balding, frail and small" and coded no when it read "Casually they dress like everyone else, but at work they wear proper lab gear". Explicit stereotype resistance included statements such as: "like average everyday people" or "a normal person".

TABLE I. Measures used in the study.

\begin{tabular}{|c|c|c|c|c|c|}
\hline Construct & Scale & Example item & No. of items & Cronbach's $\alpha$ & References \\
\hline \multicolumn{6}{|c|}{ Characteristics about people } \\
\hline Warmth & $\begin{array}{c}1 \text { (not at all) to } 5 \\
\text { (extremely) }\end{array}$ & $\begin{array}{l}\text { Consider how physicists are viewed by } \\
\text { Americans in general. As viewed by most } \\
\text { Americans, how warm are physicists or } \\
\text { biologists? }\end{array}$ & 2 & 0.88 & {$[51]$} \\
\hline Competence & $\begin{array}{c}1 \text { (not at all) to } 5 \\
\text { (extremely) }\end{array}$ & $\begin{array}{l}\text { Consider how physicists are viewed by } \\
\text { Americans in general. As viewed by most } \\
\text { Americans, how competent are physicists or } \\
\text { biologists? }\end{array}$ & 2 & 0.80 & {$[51]$} \\
\hline Working alone & $\begin{array}{c}1 \text { (not at all) to } 5 \\
\text { (extremely) }\end{array}$ & $\begin{array}{l}\text { Please indicate to what extent each } \\
\text { characteristic best describes society's beliefs } \\
\text { and expectations that physicists or biologists } \\
\text { are: Usually work alone }\end{array}$ & 1 & $\cdots$ & {$[16,54]$} \\
\hline Single minded & $\begin{array}{c}1 \text { (not at all) to } 5 \\
\text { (extremely) }\end{array}$ & $\begin{array}{l}\text { Please indicate to what extent each } \\
\text { characteristic best describes society's beliefs } \\
\text { and expectations that physicists or biologists } \\
\text { are: Focused on their subject }\end{array}$ & 1 & $\cdots$ & {$[16,54]$} \\
\hline
\end{tabular}


TABLE I. (Continued)

\begin{tabular}{|c|c|c|c|c|c|}
\hline Construct & Scale & Example item & No. of items & Cronbach's $\alpha$ & References \\
\hline Tech oriented & $\begin{array}{c}1 \text { (not at all) to } 5 \\
\text { (extremely) }\end{array}$ & $\begin{array}{l}\text { Please indicate to what extent each } \\
\text { characteristic best describes society's beliefs } \\
\text { and expectations that physicists or biologists } \\
\text { are: Technology oriented }\end{array}$ & 1 & $\cdots$ & {$[16,54]$} \\
\hline Balanced life & $\begin{array}{c}1 \text { (not at all) to } 5 \\
\text { (extremely) }\end{array}$ & $\begin{array}{l}\text { Please indicate to what extent each } \\
\text { characteristic best describes society's beliefs } \\
\text { and expectations that physicists or biologists } \\
\text { are: Have a balanced life }\end{array}$ & 1 & $\cdots$ & {$[16,54]$} \\
\hline Interpersonal skills & $\begin{array}{c}1 \text { (not at all) to } 5 \\
\text { (extremely) }\end{array}$ & $\begin{array}{l}\text { Please indicate to what extent each } \\
\text { characteristic best describes society's beliefs } \\
\text { and expectations that physicists or biologists } \\
\text { are: Popular or socially awkward or hopeless } \\
\text { with the opposite sex }\end{array}$ & 3 & 0.72 & {$[16,54]$} \\
\hline Attractive & $\begin{array}{c}1 \text { (not at all) to } 5 \\
\text { (extremely) }\end{array}$ & $\begin{array}{l}\text { Please indicate to what extent each } \\
\text { characteristic best describes society's beliefs } \\
\text { and expectations that physicists or biologists } \\
\text { are: attractive or athletic }\end{array}$ & 2 & 0.68 & {$[16,54]$} \\
\hline Intelligent & $\begin{array}{c}1 \text { (not at all) to } 5 \\
\text { (extremely) }\end{array}$ & $\begin{array}{l}\text { Please indicate to what extent each } \\
\text { characteristic best describes society's beliefs } \\
\text { and expectations that physicists or biologists } \\
\text { are: Intelligent or clever }\end{array}$ & 2 & 0.66 & {$[16,54]$} \\
\hline \multicolumn{6}{|c|}{ Characteristics about the field } \\
\hline $\begin{array}{l}\text { Requires natural } \\
\text { talent }\end{array}$ & $\begin{array}{c}1 \text { (not at all) to } 5 \\
\text { (extremely) }\end{array}$ & $\begin{array}{l}\text { Please indicate to what extent each } \\
\text { characteristic best describes society's beliefs } \\
\text { and expectations for a job in physics or } \\
\text { biology. A job in physics or biology: } \\
\text { Requires natural talent }\end{array}$ & 1 & $\cdots$ & {$[52]$} \\
\hline $\begin{array}{c}\text { Requires a great } \\
\text { deal of effort }\end{array}$ & $\begin{array}{c}1 \text { (not at all) to } 5 \\
\text { (extremely) }\end{array}$ & $\begin{array}{l}\text { Please indicate to what extent each } \\
\text { characteristic best describes society's beliefs } \\
\text { and expectations for a job in physics or } \\
\text { biology. A job in physics or biology: Takes a } \\
\text { lot of effort to succeed }\end{array}$ & 1 & $\cdots$ & {$[52]$} \\
\hline Interesting & $\begin{array}{c}1 \text { (not at all) to } 5 \\
\text { (extremely) }\end{array}$ & $\begin{array}{l}\text { Please indicate to what extent each } \\
\text { characteristic best describes society's beliefs } \\
\text { and expectations for a job in physics or } \\
\text { biology. A job in physics or biology: } \\
\text { Is interesting }\end{array}$ & 1 & $\cdots$ & {$[52]$} \\
\hline Difficult & $\begin{array}{c}1 \text { (not at all) to } 5 \\
\text { (extremely) }\end{array}$ & $\begin{array}{l}\text { Please indicate to what extent each } \\
\text { characteristic best describes society's beliefs } \\
\text { and expectations for a job in physics or } \\
\text { biology. A job in physics or biology: Is } \\
\text { difficult }\end{array}$ & 1 & $\cdots$ & {$[52]$} \\
\hline Creative & $\begin{array}{c}1 \text { (not at all) to } 5 \\
\text { (extremely) }\end{array}$ & $\begin{array}{l}\text { Please indicate to what extent each } \\
\text { characteristic best describes society's beliefs } \\
\text { and expectations for a job in physics or } \\
\text { biology. A job in physics or biology: Allows } \\
\text { for creative expression }\end{array}$ & 1 & $\cdots$ & {$[52]$} \\
\hline Stressful & $\begin{array}{c}1 \text { (not at all) to } 5 \\
\text { (extremely) }\end{array}$ & $\begin{array}{l}\text { Please indicate to what extent each } \\
\text { characteristic best describes society's beliefs } \\
\text { and expectations for a job in physics or } \\
\text { biology. A job in physics or biology: } \\
\text { Is stressful }\end{array}$ & 1 & $\cdots$ & [52] \\
\hline
\end{tabular}


TABLE I. (Continued)

\begin{tabular}{|c|c|c|c|c|c|}
\hline Construct & Scale & Example item & No. of items & Cronbach's $\alpha$ & References \\
\hline $\begin{array}{l}\text { Communal } \\
\text { affordances }\end{array}$ & $\begin{array}{c}1 \text { (not at all) to } 5 \\
\text { (extremely) }\end{array}$ & $\begin{array}{l}\text { Please indicate to what extent each } \\
\text { characteristic best describes society's beliefs } \\
\text { and expectations are for a person who is a } \\
\text { physicist or biologist. How much does a } \\
\text { physicist or biologist: Help others or serve the } \\
\text { community or work with people }\end{array}$ & 6 & 0.89 & {$[55]$} \\
\hline $\begin{array}{l}\text { Agentic } \\
\text { affordances }\end{array}$ & $\begin{array}{c}1 \text { (not at all) to } 5 \\
\text { (extremely) }\end{array}$ & $\begin{array}{l}\text { Please indicate to what extent each } \\
\text { characteristic best describes society's beliefs } \\
\text { and expectations are for a person who is a } \\
\text { physicist or biologist. How much does a } \\
\text { physicist or biologist: Have high status or get } \\
\text { financial awards or have power }\end{array}$ & 6 & 0.80 & {$[55]$} \\
\hline Masculine & $\begin{array}{c}1 \text { (not at all) to } 5 \\
\text { (extremely) }\end{array}$ & $\begin{array}{l}\text { Please indicate to what extent each } \\
\text { characteristic best describes society's beliefs } \\
\text { and expectations for a job in physics or } \\
\text { biology. A job in physics or biology: Is } \\
\text { masculine }\end{array}$ & 1 & $\cdots$ & {$[52]$} \\
\hline Feminine & $\begin{array}{c}1 \text { (not at all) to } 5 \\
\text { (extremely) }\end{array}$ & $\begin{array}{l}\text { Please indicate to what extent each } \\
\text { characteristic best describes society's beliefs } \\
\text { and expectations for a job in physics or } \\
\text { biology. A job in physics or biology: Is } \\
\text { feminine }\end{array}$ & 1 & $\cdots$ & {$[52]$} \\
\hline \multicolumn{6}{|c|}{ Emotions towards scientists } \\
\hline Pity & $\begin{array}{c}1 \text { (not at all) to } 5 \\
\text { (extremely) }\end{array}$ & $\begin{array}{l}\text { Now we are going to ask you about some } \\
\text { feelings that people in America have toward } \\
\text { physicists or biologists as a group. } \\
\text { To what extent do people tend to feel pity } \\
\text { toward physicists or biologists? }\end{array}$ & 2 & 0.67 & {$[51]$} \\
\hline Envy & $\begin{array}{c}1 \text { (not at all) to } 5 \\
\text { (extremely) }\end{array}$ & $\begin{array}{l}\text { Now we are going to ask you about some } \\
\text { feelings that people in America have toward } \\
\text { physicists or biologists as a group. } \\
\text { To what extent do people tend to feel jealous } \\
\text { toward physicists or biologists? }\end{array}$ & 2 & 0.78 & {$[51]$} \\
\hline Admiration & $\begin{array}{c}1 \text { (not at all) to } 5 \\
\text { (extremely) }\end{array}$ & $\begin{array}{l}\text { Now we are going to ask you about some } \\
\text { feelings that people in America have toward } \\
\text { physicists or biologists as a group. } \\
\text { To what extent do people tend to feel proud } \\
\text { toward physicists or biologists? }\end{array}$ & 2 & 0.73 & {$[51]$} \\
\hline Contempt & $\begin{array}{c}1 \text { (not at all) to } 5 \\
\text { (extremely) }\end{array}$ & $\begin{array}{l}\text { Now we are going to ask you about some } \\
\text { feelings that people in America have toward } \\
\text { physicists or biologists as a group. } \\
\text { To what extent do people tend to feel disgust } \\
\text { toward physicists or biologists? }\end{array}$ & 2 & 0.64 & {$[51]$} \\
\hline
\end{tabular}

\section{RESULTS}

Analysis overview.-Our goal was both to test for direction and degree of stereotypical perceptions of each person and field characteristic overall and to test for differences between physics and biology. We selected to use parametric tests on all of the Likert-type items, even in cases with just one item, which is a debatable choice, with varying opinions aired on the topic over the past 60 years. We choose the parametric approach for three reasons: First, there is little cause for concern on the violation of the assumption of continuous variables, as this assumption is mainly a concern with 4 or fewer interval survey options and all our items had 5 labeled scale options. Second, the underlying constructs we measured were continuous (i.e., the degree of agreement with the attributes). Third, we take care to also report effect sizes, and the violation of assumptions is most concerning with marginal effects. In the discussion section, we return to this analysis choice and the possible limitations and cautions to use when 
interpreting the data $[56,57]$. To test for value differences from neutral (the neutral midpoint value of 3 on the surveys), a one-sample $t$ test was conducted using a Bonferroni corrected probability of $p<0.001$ to avoid inflation and indicate statistical significance of $p<0.05$. To test for value differences between physics and biology, an independent sample $t$ test was conducted also using a Bonferroni corrected probability of $p<0.001$. To calculate the Bonferroni corrections we divided 0.05 by the number of tests we conducted $(0.05 / 23=0.0022)$. Because of our data analysis software, SPSS, not indicating $p$ values to the thousandths decimal place, we used a $p$ value of 0.001 to be more conservative. This correction was performed to avoid inflation of the $p$ value due to the large number of statistical analyses. We divided the $p$ value of 0.05 by the number of analyses to set a new, more conservative, statistical probability level for all analyses. This correction reduces the risk of committing a type I error [58]. The same Bonferroni correction was also conducted for the one sample $t$-test analyses that compared the means to the scale midpoints. Cohen's $d$ effect size estimates are provided to estimate a small (0.20), medium (0.50), or large (0.80) difference between physics and biology [59]. Analyses of variance (ANOVAs) were conducted to test for any main effect of participant gender, any main effect of sample source, and any interaction among those variables. Patterns converged across gender and sample source, unless otherwise noted. Chi square analyses were performed on the open-ended coding to determine if the frequency of the spontaneous response was statistically significant stereotypicality (yes or no) and stereotype resistant (yes or no) on appearance, behaviors, and interests. The full sample size $(n=378)$ was always used in the results, except where indicated with gender or sample analysis.
Characteristics about people.-See Table II for means, standard deviations, and effect sizes for differences between physics and biologists, and one-sample $t$-test values testing the ratings against the neutral point (value $=3$ ). Results reveal that although both were viewed as highly competent and intelligent, physicists were perceived as statistically significantly more competent and intelligent than biologists but statistically significantly less friendly and warm (Fig. 1). Results illustrate that, in general, physicists and biologists are stereotyped negatively, with perceptions of physicists statistically significantly more negative than biologists, as illustrated in Fig. 1. Physicists were also stereotyped as more unattractive, tech oriented, less likely to have a balanced life, and more awkward. Perceptions about what the "typical person" thinks about the scientists were statistically similar across participant gender and sample source, suggesting fairly widespread agreement on the person characteristics of both physicists and biologists. The effect sizes for the group score differences range from 0.35 to 0.70 , with warmth and intelligence having the largest effect sizes. When asked how similar the participant's beliefs and expectations are to society's beliefs and expectations that they reported on the various measures of person characteristics, a statistically significant sample difference emerged. The women in physics conference attendees felt that their personal views were less similar to society views $(M=2.03, \mathrm{SD}=0.20)$ compared to both general students $(M=2.78, \mathrm{SD}=0.10, p<0.01)$ and MTurk participants $(M=3.04, \mathrm{SD}=0.07, p<0.001)$.

Characteristics of the field.-Results of the two science fields illustrate that, in general, physics and biology are both stereotyped negatively, with perceptions of physics again

TABLE II. Descriptive statistics and $t$-test values for person characteristics of physicists and biologists.

\begin{tabular}{|c|c|c|c|c|c|c|}
\hline Variable & Condition & $n$ & $\mathrm{M}(S D)$ & $\begin{array}{c}\text { Between groups } \\
t \text { test }\end{array}$ & $\begin{array}{l}\text { Cohen's } d \text { physics } \\
\text { versus biology }\end{array}$ & $\begin{array}{l}\text { One sample } t \text { test } \\
(\text { tested value }=3 \text { ) }\end{array}$ \\
\hline \multirow[t]{2}{*}{ Warmth } & Physicist & 180 & $2.54(0.88)$ & \multirow[t]{2}{*}{$-5.70^{*}$} & \multirow[t]{2}{*}{-0.62} & $-7.05^{*}$ \\
\hline & Biologist & 159 & $3.08(0.86)$ & & & $1.11^{*}$ \\
\hline \multirow[t]{2}{*}{ Competence } & Physicist & 181 & $4.41(0.68)$ & \multirow[t]{2}{*}{$4.64^{*}$} & \multirow[t]{2}{*}{0.51} & $27.87^{*}$ \\
\hline & Biologist & 159 & $4.07(0.66)$ & & & $20.22^{*}$ \\
\hline \multirow[t]{2}{*}{ Single minded } & Physicist & 181 & $4.58(0.70)$ & \multirow[t]{2}{*}{2.27} & \multirow[t]{2}{*}{0.26} & $30.39^{*}$ \\
\hline & Biologist & 161 & $4.4(0.68)$ & & & $26.14^{*}$ \\
\hline \multirow[t]{2}{*}{ Tech oriented } & Physicist & 181 & $4.12(0.68)$ & \multirow[t]{2}{*}{$6.45^{*}$} & \multirow[t]{2}{*}{0.7} & $22.11^{*}$ \\
\hline & Biologist & 161 & $3.59(0.83)$ & & & $8.95^{*}$ \\
\hline \multirow[t]{2}{*}{ Balanced life } & Physicist & 181 & $2.55(0.89)$ & \multirow[t]{2}{*}{$-3.27^{*}$} & \multirow[t]{2}{*}{-0.35} & $-6.84^{*}$ \\
\hline & Biologist & 160 & $2.87(0.93)$ & & & -1.79 \\
\hline \multirow[t]{2}{*}{ Interpersonal skills } & Physicist & 181 & $2.29(0.84)$ & \multirow[t]{2}{*}{$-5.40^{*}$} & \multirow[t]{2}{*}{-0.57} & $-11.47^{*}$ \\
\hline & Biologist & 161 & $2.78(0.87)$ & & & $-3.15^{+}$ \\
\hline \multirow[t]{2}{*}{ Attractive } & Physicist & 181 & $2.05(0.75)$ & \multirow[t]{2}{*}{$-4.28^{*}$} & \multirow[t]{2}{*}{-0.47} & $-16.81^{*}$ \\
\hline & Biologist & 161 & $2.42(0.81)$ & & & $-9.03^{*}$ \\
\hline \multirow[t]{2}{*}{ Intelligent } & Physicist & 182 & $4.53(0.56)$ & \multirow[t]{2}{*}{$5.66^{*}$} & \multirow[t]{2}{*}{0.65} & $36.92^{*}$ \\
\hline & Biologist & 161 & $4.14(0.71)$ & & & $20.44^{*}$ \\
\hline
\end{tabular}

$\overline{{ }^{*} \text { A statistical significance level of } p<0.05 \text { after Bonferroni correction. }{ }^{+} \text {indicates a statistical significance level of }}$ $p<0.10$ after Bonferroni correction. 
5 Extremely

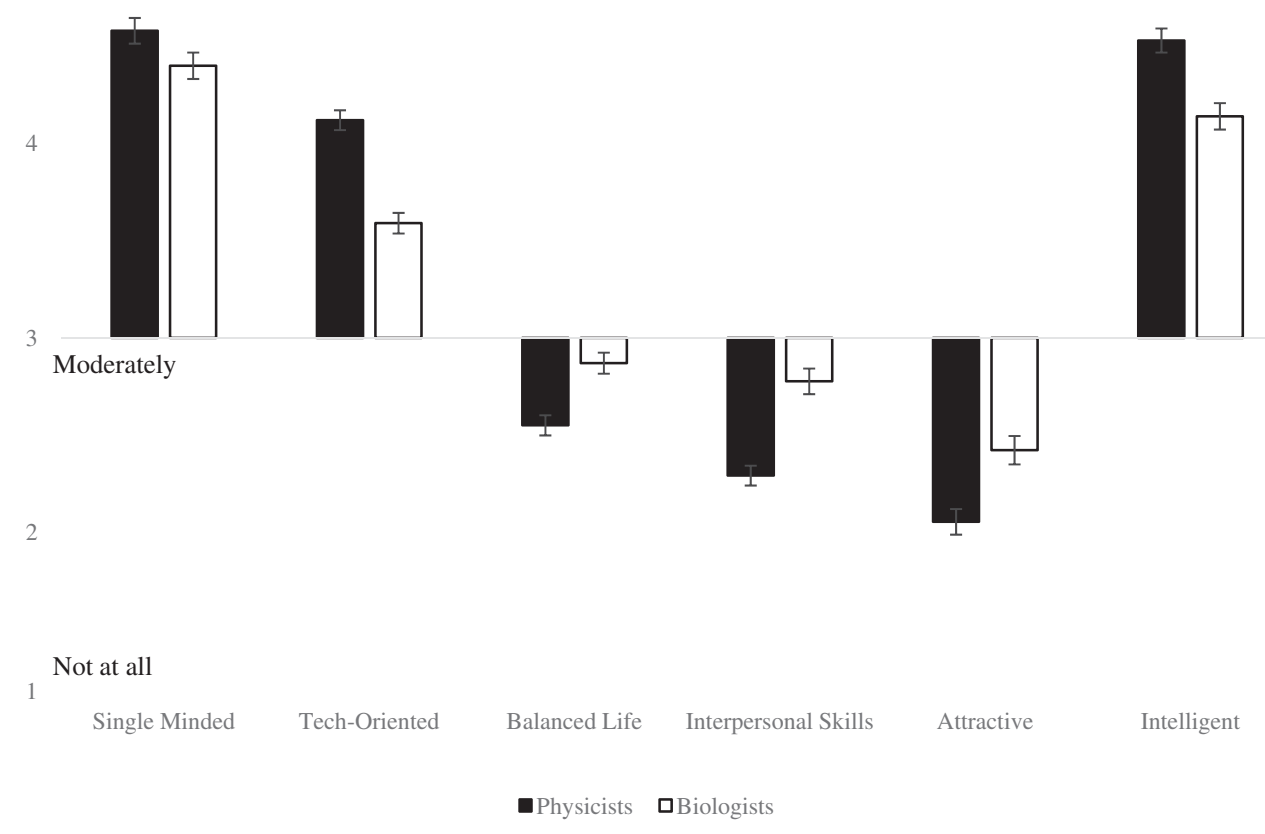

FIG. 1. Bar graph of person characteristic stereotypes. The error bars represent standard error. See Table II for sample sizes.

statistically significantly more negative than biology, as illustrated in Fig. 2 and Table III. Compared to the field of biology, physics as a field is stereotyped as a job that requires more natural talent, is more difficult, has higher agentic aspects, affords fewer opportunities for working with and helping others (communal affordances), more likely to require working alone, and is both more masculine and more feminine. The fields were viewed as similarly neutral in level of interest and allowing creative expression. The largest difference in ratings between biology and physics was for the perceived difficulty $(d=0.86)$. Ratings of stressfulness, while neutral and equal overall, differed by sample such that the MTurk participants' ratings of the stressfulness of physics were lower $(n=223, M=1.97$, $\mathrm{SD}=0.09, p<0.001)$ than both the general student sample $(n=121, M=4.06, \mathrm{SD}=0.13)$ and the women in physics conference sample $(n=34, \quad M=4.44, \quad \mathrm{SD}=0.32)$. Overall, physics was stereotyped as both requiring more natural talent and requiring more effort to succeed than biology. That said, there was a sample difference for how

5 Extremely

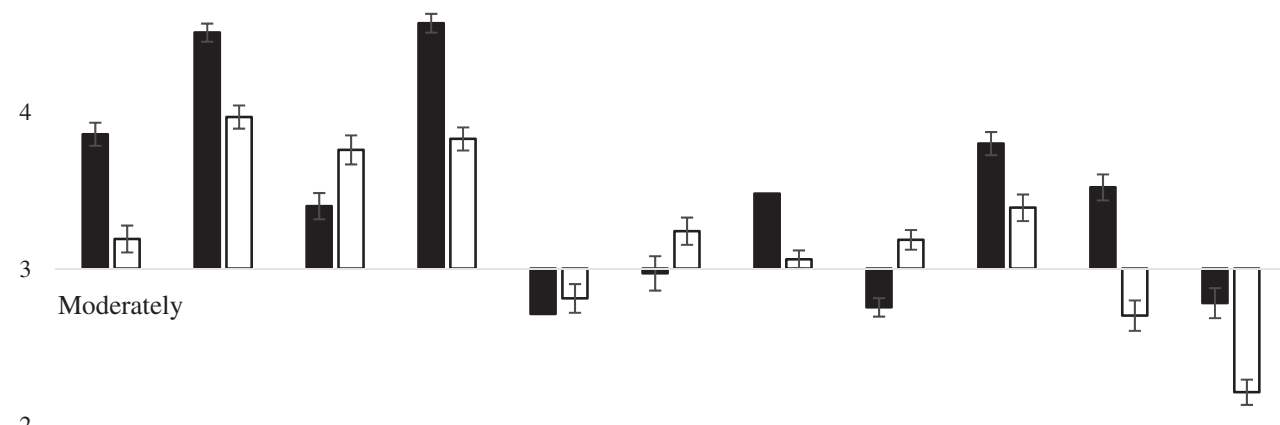

2

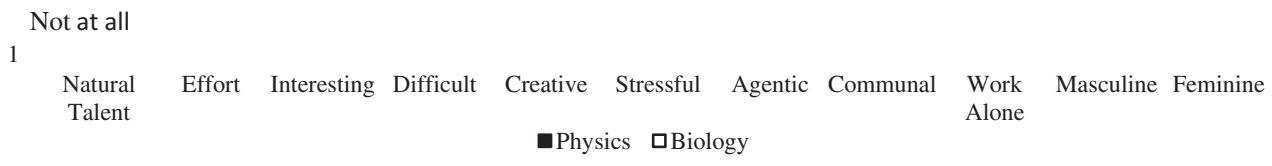

FIG. 2. Bar graph of field characteristic stereotypes. The error bars represent standard error. See Table III for sample sizes. 
TABLE III. Descriptive statistics and $t$-test values for field characteristics of physics and biology.

\begin{tabular}{|c|c|c|c|c|c|c|}
\hline Variable & Condition & $n$ & $M(\mathrm{SD})$ & $\begin{array}{c}\text { Between groups } \\
t \text { test }\end{array}$ & $\begin{array}{c}\text { Cohen's } d \text { physics } \\
\text { versus biology }\end{array}$ & $\begin{array}{l}\text { One sample } t \text { test } \\
(\text { tested value }=3 \text { ) }\end{array}$ \\
\hline \multirow{2}{*}{$\begin{array}{l}\text { Requires natural } \\
\text { talent }\end{array}$} & Physics & 180 & $3.86(1.00)$ & $5.92^{*}$ & 0.65 & $11.60^{*}$ \\
\hline & Biology & 156 & $3.19(1.07)$ & & & 2.24 \\
\hline \multirow{2}{*}{$\begin{array}{c}\text { Requires a great } \\
\text { deal of effort }\end{array}$} & Physics & 179 & $4.51(0.77)$ & $5.76^{*}$ & 0.63 & $26.06^{*}$ \\
\hline & Biology & 156 & $3.97(0.92)$ & & & $13.19^{*}$ \\
\hline \multirow[t]{2}{*}{ Interesting } & Physics & 180 & $3.40(1.13)$ & $-2.85^{+}$ & -0.31 & $4.76^{*}$ \\
\hline & Biology & 156 & $3.76(1.16)$ & & & $8.14^{*}$ \\
\hline \multirow[t]{2}{*}{ Difficult } & Physics & 180 & $4.57(0.79)$ & $7.86^{*}$ & 0.86 & $26.32^{*}$ \\
\hline & Biology & 155 & $3.83(0.93)$ & & & $11.09^{*}$ \\
\hline \multirow[t]{2}{*}{ Creative } & Physics & 181 & 2.71(1.29) & -0.80 & -0.08 & $-3.03^{+}$ \\
\hline & Biology & 156 & $2.81(1.15)$ & & & -2.03 \\
\hline \multirow[t]{2}{*}{ Stressful } & Physics & 180 & $2.97(1.42)$ & -1.98 & -0.34 & -0.32 \\
\hline & Biology & 156 & $3.40(1.13)$ & & & 2.73 \\
\hline \multirow[t]{2}{*}{ Agentic } & Physics & 181 & $3.48(0.67)$ & $5.63^{*}$ & 0.60 & $9.72^{*}$ \\
\hline & Biology & 159 & $3.06(0.72)$ & & & 1.03 \\
\hline \multirow[t]{2}{*}{ Communal } & Physics & 181 & $2.75(0.79)$ & $-5.00^{*}$ & -0.54 & $-4.15^{*}$ \\
\hline & Biology & 159 & $3.18(0.79)$ & & & $2.97^{+}$ \\
\hline \multirow[t]{2}{*}{ Work alone } & Physics & 180 & $3.80(0.99)$ & $3.69^{*}$ & 0.40 & $10.80^{*}$ \\
\hline & Biology & 160 & $3.39(1.07)$ & & & $4.58^{*}$ \\
\hline \multirow[t]{2}{*}{ Masculine } & Physics & 180 & $3.52(1.11)$ & $6.49^{*}$ & 0.71 & $6.24^{*}$ \\
\hline & Biology & 158 & $2.70(1.20)$ & & & 3.14 \\
\hline \multirow[t]{2}{*}{ Feminine } & Physics & 179 & $2.78(1.29)$ & $4.59^{*}$ & 0.51 & -2.27 \\
\hline & Biology & 156 & $2.21(1.01)$ & & & $-9.79^{*}$ \\
\hline
\end{tabular}

* indicates a statistical significance level of $p<0.05$ after Bonferroni correction.

+ indicates a statistical significance level of $p<0.10$ after Bonferroni correction.

much physics requires natural talent such that the conference attendee "insider" sample $(M=4.32, \mathrm{SD}=0.20)$ assumed others stereotyped the field as requiring more natural talent than both "outsider" samples; MTurk participants $(M=3.57, \mathrm{SD}=0.07, p<0.001)$ and general students $(M=3.31, \mathrm{SD}=0.10, p<0.005)$.

Physics was also stereotyped overall as both more masculine and more feminine than biology. Femininity ratings also indicated sample effects such that MTurk participants rated the femininity of physics statistically significantly higher $(M=2.83, \mathrm{SD}=0.08, p<0.001)$ than both the general student sample $(M=2.13, \mathrm{SD}=0.11)$ and the undergraduate women in physics conference sample
$(M=1.64, \mathrm{SD}=0.21)$. Masculinity ratings also revealed a participant gender difference such that women viewed both fields as statistically significantly more masculine $(M=3.35, \quad \mathrm{SD}=0.09)$ than men $\operatorname{did}(M=2.85$, $\mathrm{SD}=0.10, p<0.01$ ). The insider sample (women in physics conference attendees) once again felt that their personal views about physics were less similar to society views $(M=1.88, \mathrm{SD}=0.16)$ compared to general students $(M=3.02, \mathrm{SD}=0.08, p<0.001)$ and MTurk participants $(M=3.17, \mathrm{SD}=0.06, p<0.001)$.

Emotions towards scientists.- - Results demonstrate that envy was low for both type of scientists, although physicists generated relatively more envy compared to biologists.

TABLE IV. Descriptive statistics and $t$-test values for emotions.

\begin{tabular}{|c|c|c|c|c|c|c|}
\hline Variable & Condition & $n$ & $M(\mathrm{SD})$ & $\begin{array}{c}\text { Between groups } \\
t \text { test }\end{array}$ & $\begin{array}{c}\text { Cohen's } d \text { physics } \\
\text { versus biology }\end{array}$ & $\begin{array}{l}\text { One sample } t \text { test } \\
\text { (tested value }=3 \text { ) }\end{array}$ \\
\hline \multicolumn{7}{|l|}{ Emotions } \\
\hline \multirow[t]{2}{*}{ Pity } & Physics & 180 & $1.86(0.93)$ & \multirow[t]{2}{*}{1.99} & \multirow[t]{2}{*}{0.22} & $-16.34^{*}$ \\
\hline & Biology & 163 & $1.67(0.80)$ & & & $-21.35^{*}$ \\
\hline \multirow[t]{2}{*}{ Envy } & Physics & 180 & $2.33(1.04)$ & \multirow[t]{2}{*}{$4.17^{*}$} & \multirow[t]{2}{*}{0.45} & $-8.66^{*}$ \\
\hline & Biology & 163 & $1.90(0.84)$ & & & $-16.65^{*}$ \\
\hline \multirow[t]{2}{*}{ Admiration } & Physics & 181 & $3.51(0.90)$ & \multirow[t]{2}{*}{$3.35^{*}$} & \multirow[t]{2}{*}{0.36} & $7.64^{*}$ \\
\hline & Biology & 163 & $3.19(0.87)$ & & & 2.79 \\
\hline \multirow[t]{2}{*}{ Contempt } & Physics & 180 & $1.73(0.88)$ & \multirow[t]{2}{*}{2.2} & \multirow[t]{2}{*}{0.25} & $-19.32^{*}$ \\
\hline & Biology & 163 & $1.53(0.74)$ & & & $-25.16^{*}$ \\
\hline
\end{tabular}

*A statistical significance level of $p<0.05$ after Bonferroni correction. 
5 Extremely

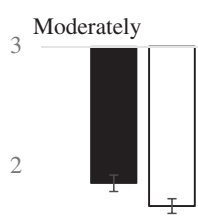

1 Not at all Pity

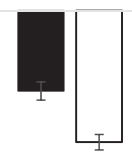

Envy Admiration
@Physics \Biology

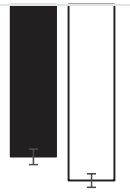

Contempt
FIG. 3. Bar graph of emotions towards scientists. The error bars represent standard error. See Table IV for sample sizes.

As shown in Table IV, people generally did not report feelings of pity, envy, or contempt for biologists or physicists. For physicists in particular, admiration was the only statistically significant emotion reported by respondents, see also Fig. 3 . A statistically significant sample difference was present only for feelings of contempt for physicists such that MTurk participants reported statistically significantly lower levels of contempt $(M=1.46, \mathrm{SD}=0.082, p<0.01)$ than general students $(M=1.87, \mathrm{SD}=0.12, p<0.001)$ or women in physics conference attendees $(M=2.52, \mathrm{SD}=0.30)$.

Spontaneous stereotype assessment of appearance, actions, and interests.-Chi-square analysis indicated that spontaneous judgments about what does the typical scientist "act like" or "look like" were mostly stereotypical, emerging about half the time for both types of scientists. Spontaneous judgments about what scientists like to "do for fun" were less likely to adhere to a stereotype. Across the three questions, however, participants did report statistically-significantly more stereotypic responses for physicists, see Table V. This indicates that participants generated more stereotypical spontaneous answers for physicists than biologists than would be expected by chance, and suggests that spontaneous biologists' stereotypes seem to have more variability. Importantly, results also show that people were equally likely (and about half the time) to explicitly resist stereotypes of what does the typical scientist "act like," "look like," or "do for fun" and this was equally true for physicists and biologists judgments. Open-ended results were similar across samples and for both men and women participants. Overall, results provide useful triangulation of survey data illustrating that participants view physicists as being higher in stereotypical traits than biologists.

\section{DISCUSSION}

Before we can change the stereotypes about science, we must first drill down into what needs to be changed. As part of this effort, we set out to understand the public's view of science and scientists, and the scientist's view of the public's view, with a focus on physics (of which very little is known) [16] using biology as a comparison. Data from our general undergraduate sample, from the MTurk worker sample, and from the undergraduate women in physics conference attendees all paint a similar disheartening picture of physics and biology; by and large there is agreement across samples regarding the negative stereotypes about the scientists' appearance, behaviors, personalities, attitudes, and both fields' working conditions and values.

Results did show some relative differences in the degree of stereotypes. Compared to biologists, physicists were perceived as statistically significantly more unattractive, tech-oriented, awkward, and loners, who have a job that affords more opportunities for agency and requires more effort to succeed. The largest degree of difference between physicists and biologists, however, varied along the indices related to warmth and competence, as determined by large Cohen's d effect sizes. Across samples, there was uniform agreement that compared to biologists, physicists are stereotyped as highly intelligent, not at all warm and friendly, and work in a field that is very difficult and does not support communal goals of working with and helping others. Thus, although there was an overall monolithic view of both physics and biology, there emerged an important relative degree of difference (ranging from medium to large differences) in stereotypes about warmth and competence.

The nearly identical results across samples speaks to the pervasive nature of the stereotypes. On only one field

TABLE V. Frequency analyses for spontaneous stereotypes from open-ended items, $n=378$.

\begin{tabular}{|c|c|c|c|c|}
\hline & Physics & Biology & $X^{2}(\mathrm{df})$ & $p$ \\
\hline \multicolumn{5}{|l|}{ What does the typical [scientist] look like? } \\
\hline Stereotypical response & $58.90 \%$ & $41.10 \%$ & $7.52(1)$ & 0.006 \\
\hline Stereotype resistance & $51.30 \%$ & $48.70 \%$ & $0.46(1)$ & 0.50 \\
\hline \multicolumn{5}{|l|}{ What does the typical [scientist] act like? } \\
\hline Stereotypical response & $57.30 \%$ & $42.75 \%$ & $8.12(1)$ & 0.004 \\
\hline Stereotype resistance & $47.70 \%$ & $52.30 \%$ & $0.67(1)$ & 0.41 \\
\hline \multicolumn{5}{|l|}{ What does the typical [scientist] like to do for fun? } \\
\hline Stereotypical response & $35.30 \%$ & $13.60 \%$ & $13.06(1)$ & $<0.001$ \\
\hline Stereotype resistance & $53.70 \%$ & $46.30 \%$ & $0.01(1)$ & 0.95 \\
\hline
\end{tabular}


stereotype did the conference attendee insider sample differ from the others; conference attendees assumed others stereotyped physics as requiring more natural talent than both outsider samples. The "brilliance" expectations of physics as viewed by insiders maps onto gender and racial distributions; this is important due to the expected brilliance or importance of genius in a field predicting lower representation of women and African Americans in the field [31]. It is noted that the samples did differ in how much they felt their personal views were similar to society's beliefs such that as one might expect, the insider sample of women in physics conference attendees felt their personal beliefs were less in line with society's stereotypes.

\section{A. Contributions to the literature}

These data contribute to our understanding of group and field stereotypes, and illustrate some interesting connections with emotions toward scientists. Our findings that the warmth and competence ratings produced the biggest difference between physicists and biologists is in line with predictions by the stereotype content model [60] and the model's derivative behaviors from intergroup affect and stereotypes (BIAS) map [51]. Research using the stereotype content model and the BIAS map use stereotypical ratings of warmth (e.g., friendly, sincere) and competence (e.g., capable, smart) to form clusters of groups, and our data are the first to provide physicists and biologists to this body of knowledge $[51,61]$. Indeed, the stereotype content model [60] has a long tradition in psychology research, illustrating how warmth or competence clusters emerge for various groups. For example, some groups are perceived as low competence or high warmth, such as older adults and people who are disabled, whereas some groups are perceived as high competence or low warmth, such as the financially wealthy and people who are Asian [51].

Knowing a group's stereotype content along the warmth and competence dimensions is an important contribution as such data help inform predictions about society's affect, attitudes, and likely behaviors toward those groups [51,61]. A group's warmth and competence perceptions triggers different types of threat to the perceiver; only groups stereotyped as highly competent elicit a threat [61]. Knowing the type and level of threat predicts one of four emotions that mediate different actions directed at the various groups, such as active facilitation (helping) or passive harm (neglecting). Those groups stereotyped as high in both warmth and competence, for example, should result in admiration which results in both active facilitation as well as passive facilitation (convenient cooperation). In contrast, a group stereotyped low in competence but high in warmth should produce feelings of pity which cues active attempts to help but also neglect (passive harm). A group stereotyped low in warmth but high in competence should produce feelings of envy which should result in passive facilitation. Lastly, a group stereotyped low in competence and low in warmth should elicit feelings of contempt or disgust which would result in both passive and active harm [51,60,61].

Our data contribute to the stereotype content model [60] and the extension to the BIAS Map [51] by assessing the stereotypical ratings of warmth and competence of our two groups of scientists, and measuring emotions. In our study, physicists were rated low in warmth and high in competence. The BIAS MAP prediction is that such groups stereotyped as low in warmth and high in competence should trigger feelings of envy which is associated with passive facilitation (e.g., not object to the March for Science, but does not attend) and active harm (e.g., attending a counterprotest). However, our results revealed little evidence of any elicited emotion of pity, envy, or contempt. See Fig. 4 for predicted emotions and actions as well as the mean warmth and competence ratings for physicists and biologists. For physicists, admiration was the only statistically significant emotion reported by respondents when comparing biologists and physicists. According to the BIAS MAP, admiration is associated with both active facilitation (e.g., donating to science charities) and passive facilitation (e.g., not objecting to tax dollars going to external funding) $[51,61]$. Thus, our data illustrate a dissimilarity between warmth and competence ratings and the predictions by the BIAS map.

Why envy was not elicited, as would be expected, is unclear. It is possible that the general public does not hold any well-established thoughts or opinions on physicists and biologists and do not have enough exposure to them to develop these beliefs or expected feelings [51]. This is among the first study to our knowledge to examine specific

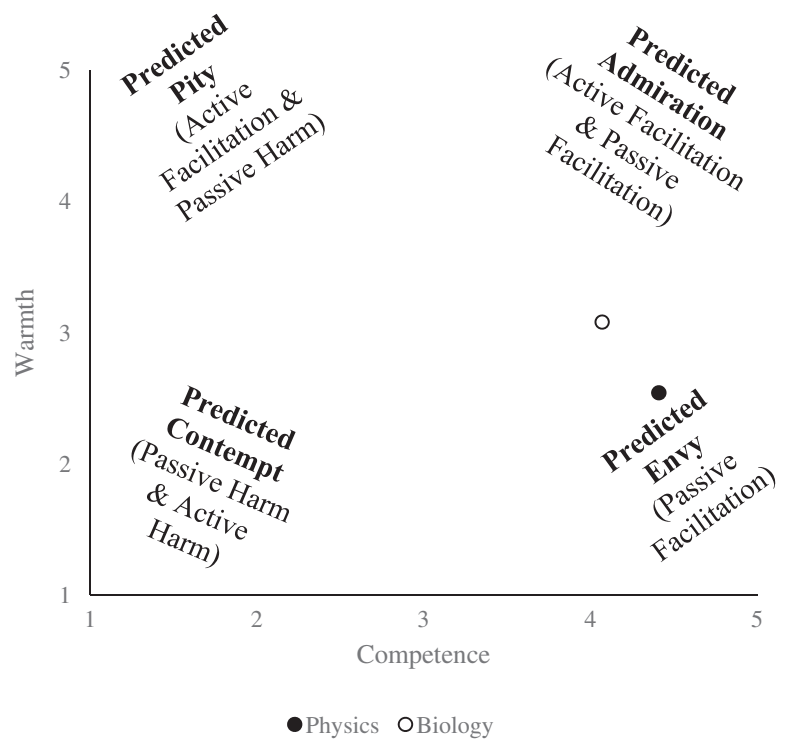

FIG. 4. Scatter plot of results for physicists and biologists on competence and warmth ratings. BIAS map emotion predictions are represented within the figure [51]. Actual emotion results are reported in Fig. 3. See Table I for sample size. 
types of scientists, thus we can only offer speculation at this point. The groups used as targets for the BIAS map ratings are typically more relatively visible and common groups, such as whites, the elderly, feminists, housewives, and welfare recipients. These are groups that participants may have more personal experience with than people in individual science fields (biology and physics). Therefore, our findings which do not fully support the BIAS map predictions, could be due to the lack of exposure to people in the sciences and is an important and interesting theoretical question for future research.

Physics was perceived as a field simultaneously more masculine and feminine than biology. Why might this be? Understanding different forms of masculinity might help to make sense of this seemingly odd finding. Masculinity takes many forms [62]. Hegemonic masculinity, for example, is a masculine expression or practice that centers around men's power and dominance over women, with often rigid and forceful expressions. Subordinate masculinity, in contrast, can and has often been conflated with femininity [62] as this form of expression includes being acted upon (for example, bullied) as a less powerful member of a patriarchal society. It is possible that some participants are viewing physics as a field high in subordinate masculinity which they are articulating as femininity in our survey. The lack of women in the field certainly lends itself to the stereotype that the field is masculine [17]. Putting these two ideas together, would result in high ratings of both masculinity and femininity. More research is needed to understand different forms of masculinity in science contexts and whether and how such masculinity expectations contribute or not to recruitment and retention in science fields.

\section{B. Limitations and future directions}

Limitations of the current study need to be acknowledged. We have three samples at one moment in time and MTurk was our only national sample whereas the other two samples were confined to the regional mountain west in the U.S. Future directions should examine how stereotypes generalize across regions and stay stable or fluctuate over time. Moreover, this research was descriptive and limited to the use of person and field traits borrowed from past related work. Add to this that our choice to analyze even single item variables with parametric tests, and caution is warranted in overinterpreting the results. Decades of debate on the use of single items [56,57] is reemerging as part of the Carnegie movement for "practical measurement" in research [63] which calls for face-valid, single item construct measurement that is quicker and easier to administer. Although we are confident that our analyses did not violate the assumptions of continuous variables in a way that hampers the interpretation of results, replication with different (and more) measures and different and more samples is necessary; we hope that our study inspires such follow-ups. Indeed, future research would also do well to replicate these results with other more subtle measures of stereotypes. For example, examine responses to physics or biology related humor and jokes, similar to research on age or jokes [64], or test how people might penalize mistakes or unpopular decisions made by physicists versus biologists, modeling, for example, gender nonconforming studies in leadership [65].

Another limitation is that we asked about physicist and biologist stereotypes without reference to gender or ethnicity and assumed we were unpacking the "old white man" stereotype. Future work could ask people to generate stereotypes about specific scientists using an intersectional lens [66] to examine differences in stereotypes about people with multiple identities to see if stereotypes are fairly uniform or variable. This would allow us to discover, for example, how people might try to cluster "surprising" combinations of person stereotypes (Latinx, physicist, and gay) [67]. Using an intersectionality approach would help avoid the assumption of rigid categories of stereotypes and instead add depth, visibility, and complexity to better understand the content and meaning of science stereotypes. Understanding and discussing the multiple layers of difference, identity, and oppression is key in order to reveal more nuanced information about the systems of privilege and power within science [68].

One important future direction for research is to look at situations that can refute (versus reinforce) stereotypes. Cheryan, Plaut, Davies, and Steele [69] provide an example of how these stereotypes occur in real life situations and have implications for people's science participation motivation. In that research, a computer science environment that was filled with stereotypical items such as a Star Trek poster and programming books caused women to report less belonging and less interest compared to women in a room with nature posters and general books (men were unaffected). These results illustrate that people often look for (stereotypical) signs that they belong in a given field. Future research should continue to examine stereotype accessibility and specific links to career pursuits [40] and trust in science [70].

\section{Implications}

The current study intentionally focused on physics as the first systematic assessment of physics stereotypes. Biology was chosen as a comparison field to physics due to the difference in the number of women in the field and because both fields are lacking domestic ethnic and racial diversity [71]. There has been a steady increase since 1971 of firstyear female undergraduate students indicating they would like to major in biology; no such trend is seen in women's interest in physics [7]. Indeed, our results suggest that physics stereotypes are more extreme than biology stereotypes; although stereotypes of both fields and people were generally negative. 
Science educators can take steps to address some of the specific negative stereotypes uncovered here. For example, knowing that one of the stereotypes about physics is that it requires natural talent, educators can turn to the growth mindset literature for solutions. Research shows belief in a fixed mindset (versus growth oriented) creates mistrust and fear of stereotyping $[44,72,73]$. As such, to confront the stereotype that learning physics requires natural talent, students can be asked to read and write about a growth mindset [74] or can read promotional materials that describe the specific science field as valuing effort [39]. A similar approach can be used for other stereotypes identified in this research. As just one more example, to counteract the stereotype that physics is seen as not affording opportunities to work with and help others, educators can turn to communal goals research that illustrates how reading about "the day in the life of a scientist" role model who actively works with and helps others improves science positivity and career goal intentions [75]. Indeed, (nonstereotypical) role models are one useful tool to consider using to unravel science stereotypes [76].

More generally, educators might consider finding ways to increase physics students' sense of belonging in the classroom through a writing activity in which the student writes to a hypothetical future physics student [77] as this technique closes the gender gap in grades, and may combat the stereotype that physics students are "geeky." Indeed, brief "values affirmation" writing interventions show great promise in negating belonging uncertainty and closing achievement gaps with both physics students [78] and biology students [79]; it remains to be seen whether and how such affirming assignments might combat stereotypes.

Results from this study illustrate that physics educators in particular would do well to consider that strong (and often negative) stereotypes regarding physicists and the field of physics exist, and students likely come to physics classes frequently holding these stereotypes. While in a classroom setting, educators have an opportunity to combat specific stereotypes, which can affect the overall number and types of people attracted to the field. In order to effectively address and help students overcome these negative stereotypes, physics educators can use these results to inform which stereotypes they wish to undo, while taking care not to single out specific groups for the interventions, by dealing with the specific concerns of students, and by keeping the delivery brief and not repetitive [80]. Two other recent works have specific suggestions for action at the classroom, department, and institutional levels [14,71]. At the department level, the Conference for Undergraduate Women in Physics is held each year and can be a great tool to recruit women and minorities at the undergraduate and graduate level. The American Physical Society offers both monetary and logistical support to host these conferences.

\section{Conclusion}

Our work contributes to both the applied understanding of physics and biology perceptions, and to the broader literature on stereotypes. As reviewed at the outset, stereotypes impact recruitment and retention [7-11], trigger overgeneralizations about expectations of work values [40], and impede everyone's motivation to participate in science. There are thus many reasons to care about identifying specific stereotypes about scientists as people and the fields of science in which they work, not the least of which is that such identification is the first step in developing and implementing interventions that break down those stereotypes. Stereotypes limit broad participation by people from all walks of life-who do not match the stereotypes-in the science workforce [25]. There are social justice reasons to care about a diverse science workforce and there are also grand economic, environmental, and public health and safety challenges that are constrained by a homogenous workforce and hence less diverse collaborations within physics [4]. Broadening the participation of who does science fosters scientific progress [81]. When the full range of people are turned off by stereotypes, innovation and creativity decline [82] and likely contributes to American public's "crisis of faith" in science [68].

We must consider breaking down science stereotypes as imperative to advancing both physics and biology. All too often, people are selected into science if they fit the stereotypes $[33,34]$ or people are asked to assimilate to the existing stereotypes in order to succeed $[30,72,83]$. Our work offers the first look at the specific content of that "old white man sitting in a dusty laboratory" science stereotype that science educators and employers are up against. Now the hard work begins to break down those stereotypes. After all, what is good for science are those discoveries-inwaiting that come from new, creative, and different ways of knowing, being, and living.

\section{ACKNOWLEDGMENTS}

This research was funded in part by the National Science Foundation under Grant No. HRD-1208831. Any opinions, findings, and conclusions or recommendations expressed in this manuscript are those of the authors and do not necessarily reflect the views of the National Science Foundation. The authors wish to thank the students in the Motivation and Diversity Lab for their assistance with data collection and coding. 
[1] J. M. Chen and D. L. Hamilton, Understanding diversity: The importance of social acceptance, Pers. Soc. Psychol. Bull. 41, 586 (2015).

[2] A. Kreighbaum and Bauer-Wolf, Why they marched, Inside Higher Education (Inside Higher Education, Washington, DC, 2017).

[3] H. Garrison, Underrepresentation by race-ethnicity across stages of U.S. Science and Engineering Education, CBE Life Sci. Educ. 12, 357 (2013).

[4] H. A. Valantine and F. S. Collins, National Institutes of Health addresses the science of diversity, Proc. Natl. Acad. Sci. U.S.A. 112, 12240 (2015).

[5] B. E. Hughes, Coming out in STEM: Factors affecting retention of sexual minority STEM students, Sci. Adv. 4, eaao6373 (2018).

[6] National Science Foundation, National Science Board Science, and Engineering Indicators 2016 (National Science Foundation, Washington, 2016).

[7] L. J. Sax, K. J. Lehman, R. S. Barthelemy, and G. Lim, Women in physics: A comparison to science, technology, engineering, and math education over four decades, Phys. Rev. Phys. Educ. Res. 12, 020108 (2016).

[8] S. Cheryan, A. Master, and A. N. Meltzoff, Cultural stereotypes as gatekeepers: Increasing girls' interest in computer science and engineering by diversifying stereotypes, Front Psychol. 6, 49 (2015).

[9] J. T. Jost, M. R. Banaji, and B. A. Nosek, A decade of system justification theory: Accumulated evidence of conscious and unconscious bolstering of the status quo, Polit. Psychol. 25, 881 (2004).

[10] B. A. Nosek et al., National differences in gender-science stereotypes predict national sex differences in science and math achievement, Proc. Natl. Acad. Sci. U.S.A. 106, 10593 (2009).

[11] C. M. Steele, A threat in the air. How stereotypes shape intellectual identity and performance, Am. Psychol. 52, 613 (1997).

[12] A. Levine, The benefits of investing in interdisciplinarity, Phys. Today, doi: 10.1063/PT.6.5.20180328a (2018).

[13] J. M. Nissen and J. T. Shemwell, Gender, experience, and self-efficacy in introductory physics, Phys. Rev. Phys. Educ. Res. 12, 020105 (2016).

[14] A. M. Kelly, Social cognitive perspective of gender disparities in undergraduate physics, Phys. Rev. Phys. Educ. Res. 12, 020116 (2016).

[15] A. L. Traxler, X. C. Cid, J. Blue, and R. Barthelemy, Enriching gender in physics education research: A binary past and a complex future, Phys. Rev. Phys. Educ. Res. 12, 020114 (2016).

[16] S. Cheryan, S. A. Ziegler, A. K. Montoya, and L. Jiang, Why are some STEM fields more gender balanced than others?, Psychol. Bull. 143, 1 (2017).

[17] A. H. Eagly and A. B. Diekman, What is the problem? Prejudice as an attitude-in-context, in On the Nature of Prejudice: Fifty Years after Allport, edited by J. F. Dovidio, Glick, and L. A. Rudman (Wiley-Blackwell, New York, 2005), pp. 19-35.

[18] A. M. Koenig and A. H. Eagly, Evidence for the social role theory of stereotype content: Observations of groups' roles shape stereotypes, J. Pers. Soc. Psychol. 107, 371 (2014).
[19] J. Stone, C. I. Lynch, M. Sjomeling, and J. M. Darley, Stereotype threat effects on black and white athletic performance, J. Pers. Soc. Psychol. 77, 1213 (1999).

[20] E. R. Brown, J. L. Smith, and M. Huntoon, Stereotype effects and attributions: Inside and out, in Encyclopedia of Educational Theory and Philosophy (SAGE Publications, Inc., Thousand Oaks, CA, 2014), pp. 786-788.

[21] P. Devine, Stereotypes and prejudice: Their automatic and controlled components, J. Pers. Soc. Psychol. 56, 5 (1989).

[22] J. L. Smith, C. Sansone, and P. H. White, The stereotyped task engagement process: The role of interest and achievement motivation, J. Educ. Psychol. 99, 99 (2007).

[23] G. M. Walton and G. L. Cohen, A question of belonging: Race, social fit, and achievement, J. Pers. Soc. Psychol. 92, 82 (2007).

[24] J. L. Smith, E. Cech, A. Metz, M. Huntoon, and C. Moyer, Giving back or giving up: Native American student experiences in science and engineering, Cultur. Divers. Ethnic Minor. Psychol. 20, 413 (2014).

[25] K. L. Lewis, J. G. Stout, S. J. Pollock, N. D. Finkelstein, and T. A. Ito, Fitting in or opting out: A review of key social-psychological factors influencing a sense of belonging for women in physics, Phys. Rev. Phys. Educ. Res. 12, 020110 (2016).

[26] D. W. Sue, Microaggressions in Everyday Life: Race, Gender, and Sexual Orientation (John Wiley \& Sons, New York, 2010).

[27] L. E. Park, A. F. Young, J. D. Troisi, and R. T. Pinkus, Effects of everyday romantic goal pursuit on women's attitudes toward math and science, Pers. Soc. Psychol. Bull. 37, 1259 (2011).

[28] M. R. Banaji and C. D. Hardin, Automatic stereotyping, Psychol. Sci. 7, 136 (1996).

[29] M. Biernat and D. Kobrynowicz, Gender- and race-based standards of competence: Lower minimum standards but higher ability standards for devalued groups, J. Pers. Soc. Psychol. 72, 544 (1997).

[30] S. G. Harding, The Science Question in Feminism (Cornell University Press, Ithaca, 1986).

[31] A. Cimpian and S.-J. Leslie, The brilliance trap, Sci. Am. 317, 60 (2017).

[32] C. A. Moss-Racusin, J. F. Dovidio, V. L. Brescoll, M. J. Graham, and J. Handelsman, Science faculty's subtle gender biases favor male students, Proc. Natl. Acad. Sci. U.S.A. 109, 16474 (2012).

[33] M. Bertrand and S. Mullainathan, Are Emily and Greg more employable than Lakisha and Jamal? A field experiment on labor market discrimination (Working Paper No. 9873). National Bureau of Economic Research (2003). Retrieved from http://www.nber.org/ papers/w9873.

[34] M. Ameri, L. Schur, M. Adya, S. Bentley, P. McKay, and D. Kruse, The disability employment puzzle: A field experiment on employer hiring behavior (Working Paper No. 21560). National Bureau of Economic Research (2015). Retrieved from http://www.nber.org/papers/ w21560.

[35] J. M. Sheltzer and J. C. Smith, Elite male faculty in the life sciences employ fewer women, Proc. Natl. Acad. Sci. U.S.A. 111, 10107 (2014). 
[36] S. K. Kang, K. A. DeCelles, A. Tilcsik, and S. Jun, Whitened résumés race and self-presentation in the labor market, Admin. Sci. Q. 61, 469 (2016).

[37] J. L. Smith, E. R. Brown, D. B. Thoman, and E. D. Deemer, Losing its expected communal value: How stereotype threat undermines women's identity as research scientists, Soc. Psychol. Educ. 18, 443 (2015).

[38] D. B. Thoman, J. L. Smith, E. R. Brown, J. Chase, and J. Y. K. Lee, Beyond performance: A motivational experiences model of stereotype threat, Educ. Psychol. Rev. 25, 211 (2012).

[39] J. L. Smith, K. L. Lewis, L. Hawthorne, and S. D. Hodges, When trying hard isn't natural women's belonging with and motivation for male-dominated stem fields as a function of effort expenditure concerns, Pers. Soc. Psychol. Bull. 39, 131 (2013).

[40] A. B. Diekman, E. R. Brown, A. M. Johnston, and E. K. Clark, Seeking congruity between goals and roles a new look at why women opt out of science, technology, engineering, and mathematics careers, Psychol. Sci. 21, 1051 (2010).

[41] D. B. Thoman, E. R. Brown, A. Z. Mason, A. G. Harmsen, and J. L. Smith, The role of altruistic values in motivating underrepresented minority students for biomedicine, BioScience 65, 183 (2015).

[42] E. R. Brown, J. L. Smith, D. B. Thoman, J. M. Allen, and G. Muragishi, From bench to bedside: A communal utility value intervention to enhance students' biomedical science motivation, J. Educ. Psychol. 107, 1116 (2015).

[43] K. E. Chaney, D. T. Sanchez, and J. D. Remedios, Organizational identity safety cue transfers, Pers. Soc. Psychol. Bull. 42, 1564 (2016).

[44] D. W. Chambers, Stereotypic images of the scientist: The draw-a-scientist test, Sci. Educ. 67, 255 (1983).

[45] S. Cheryan, V. C. Plaut, C. Handron, and L. Hudson, The stereotypical computer scientist: Gendered media representations as a barrier to inclusion for women, Sex Roles 69, 58 (2013).

[46] B. T. Rutjens and S. J. Heine, The immoral landscape? Scientists are associated with violations of morality, PLoS One 11, e0152798 (2016).

[47] G. Schott and N. Selwyn, Examining the 'male, antisocial' stereotype of high computer users, J. Educ. Comput. Res. 23, 291 (2000).

[48] E. A. Cech and T. J. Waidzunas, Navigating the heteronormativity of engineering: The experiences of lesbian, gay, and bisexual students, Eng. Stud. 3, 1 (2011).

[49] G. Paolacci and J. Chandler, Inside the turk: Understanding mechanical turk as a participant pool, Curr. Dir. Psychol. Sci. 23, 184 (2014).

[50] M. Buhrmester, T. Kwang, and S. D. Gosling, Amazon's mechanical turk: A new source of inexpensive, yet highquality, data?, Perspect. Psychol. Sci. 6, 3 (2011).

[51] A. J. C. Cuddy, S. T. Fiske, and P. Glick, The BIAS map: Behaviors from intergroup affect and stereotypes, J. Pers. Soc. Psychol. 92, 631 (2007).

[52] P. G. Devine and A. J. Elliot, Are racial stereotypes really fading? The princeton trilogy revisited, Pers. Soc. Psychol. Bull. 21, 1139 (1995).
[53] J. Allen and J. L. Smith, The influence of sexuality stereotypes on men's experience of gender-role incongruence, Psychol. Men Masculinity 12, 77 (2011).

[54] S. Beyer, M. DeKeuster, K. Walter, M. Colar, and C. Holcomb, Changes in CS students' attitudes towards CS over time: An examination of gender differences, in Proceedings of the 36th SIGCSE Technical Symposium on Computer Science Education (ACM, New York, 2005), pp. 392-396.

[55] K. Pohlmann, Agency-, and communion-orientation in life goals: Impacts on goal pursuit strategies, and psychological well-being, in Life Goals, and Well-Being: Towards a Positive Psychology of Human Striving, edited by P. Schmuck and K. M. Sheldon (Hogrefe \& Huber, Boston, 2001), pp. 68-84.

[56] J. Carifio and R. Perla, Resolving the 50-year debate around using and misusing Likert scales, Med. Educ. 42, 1150 (2008).

[57] G. Norman, Likert scales, levels of measurement and the "laws" of statistics, Adv. Health Sci. Educ. 15, 625 (2010).

[58] P. Sedgwick, Multiple significance tests: The Bonferroni correction, Br. Med. J. 344, e509 (2012).

[59] K. R. Murphy, B. Myors, and A. Wolach, Statistical Power Analysis: A Simple and General Model for Traditional and Modern Hypothesis Tests, 4th ed. (Routledge, London, 2014).

[60] A. J. C. Cuddy, S. T. Fiske, and P. Glick, Warmth and competence as universal dimensions of social perception: The stereotype content model and the BIAS map, Adv. Exp. Soc. Psychol. 40, 61 (2008).

[61] S. T. Fiske, A. J. C. Cuddy, P. Glick, and J. Xu, A model of (often mixed) stereotype content: Competence and warmth respectively follow from perceived status and competition, J. Pers. Soc. Psychol. 82, 878 (2002).

[62] R. W. Connell, Masculinities (Polity Press, Cambridge, UK, 1995).

[63] D. Yeager, A. S. Bryk, J. Muhich, H. Hausman, and L. Morales, Practical Measurement (Carnegie Foundation for the Advancement of Teaching, Stanford, CA, 2013).

[64] G. Nimrod and L. Berdychevsky, Laughing off the stereotypes: Age and aging in seniors' online sex-related humor, The Gerontologist 58, 960 (2018).

[65] V. L. Brescoll, Who takes the floor and why: Gender, power, and volubility in organizations, Admin. Sci. Q. 56, 622 (2012).

[66] N. M. Else-Quest and J. S. Hyde, Intersectionality in quantitative psychological research: II. Methods and techniques, Psychol. Women Q. 40, 319 (2016).

[67] Z. Kunda, D. T. Miller, and T. Claire, Combining social concepts: The role of causal reasoning, Cogn. Sci. 14, 551 (1990).

[68] K. Mack, O. Taylor, N. Cantor, and P. McDermott, If not now, when? The promise of STEM intersectionality in the twenty-first century, Peer Review 16 (2014).

[69] S. Cheryan, V. . Plaut, P. G. Davies, and C. M. Steele, Ambient belonging: How stereotypical cues impact gender participation in computer science, J. Pers. Soc. Psychol. 97, 1045 (2009)

[70] T. L. Pittinsky, Americans crisis of faith in science, Science 348, 511 (2015). 
[71] National Science Foundation, Women, Minorities, and Persons with Disabilities in Science, and Engineering (National Science Foundation, Washington, 2017).

[72] M. C. Murphy and C. S. Dweck, A culture of genius: How an organization's lay theory shapes people's cognition, affect, and behavior, Pers. Soc. Psychol. Bull. 36, 283 (2010).

[73] J. Blue, A. L. Traxler, and X. C. Cid, Gender matters, Phys. Today 71, 40 (2018).

[74] C. Dweck, Mindset: The new psychology of success (Random House Publishing Group, New York, 2006).

[75] A. B. Diekman, E. K. Clark, A. M. Johnston, E. R. Brown, and M. Steinberg, Malleability in communal goals and beliefs influences attraction to stem careers: Evidence for a goal congruity perspective, J. Pers. Soc. Psychol. 101, 902 (2011).

[76] S. Cheryan, B. J. Drury, and M. Vichayapai, Enduring influence of stereotypical computer science role models on women's academic aspirations, Psychol. Women Q. 37, 72 (2012).

[77] D. S. Yeager and G. M. Walton, Social-psychological interventions in education: They're not magic, Rev. Educ. Res. 81, 267 (2011).
[78] A. Miyake, L. E. Kost-Smith, N. D. Finkelstein, S. J. Pollock, G. L. Cohen, and T. A. Ito, Reducing the gender achievement gap in college science: A classroom study of values affirmation, Science 330, 1234 (2010).

[79] J. M. Harackiewicz, E. A. Canning, Y. Tibbetts, C. J. Giffen, S. S. Blair, D. I. Rouse, and J. S. Hyde, Closing the social class achievement gap for first-generation students in undergraduate biology, J. Educ. Psychol. 106, 375 (2014).

[80] L. Aguilar, G. Walton, and C. Wieman, Psychological insights for improved physics teaching, Phys. Today 67, 43 (2014).

[81] K. Intemann, Why diversity matters: Understanding and applying the diversity component of the national science foundation's broader impacts criterion, Soc. Epistem. 23, 249 (2009).

[82] S. E. Page, The Difference: How the Power of Diversity Creates Better Groups, Firms, Schools, and Societies (Princeton University Press, Princeton, 2008).

[83] E. A. Cech, A. Metz, J. L. Smith, and K. deVries, Epistemological dominance and social inequality: Experiences of native american science, engineering, and health students, Sci. Tech. Hum. Val. 42, 743 (2017). 